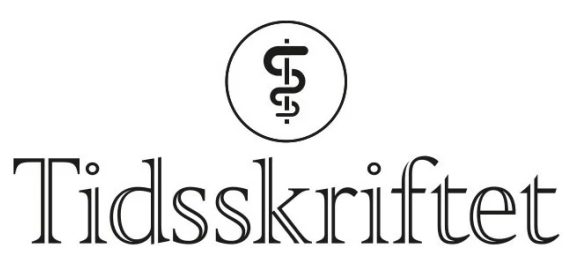

DEN NORSKE LEGEFORENING

\title{
Depresjon som verdens midtpunkt
}

\author{
ANMELDELSER
}

PER VAGLUM

Professor emeritus, Avdeling for medisinsk atferdsvitenskap Universitetet i Oslo

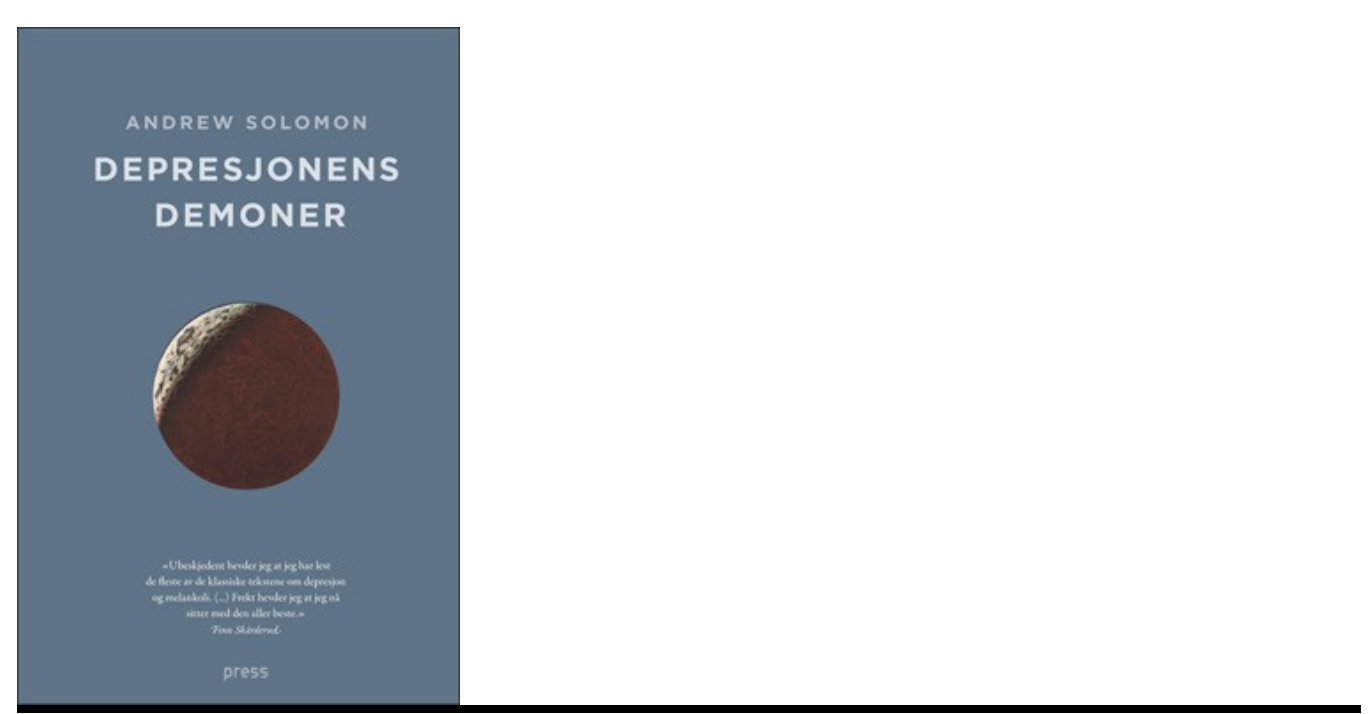

Solomon, Andrew

Depresjonens demoner

601 s. Oslo: Forlaget Press, 2014. Pris NOK 199

ISBN 978-82-7547-66o-7

Forfatteren av denne voluminøse populærvitenskapelige boken har selv en bipolar lidelse og har vært gjennom flere store «sammenbrudd» og flere typer psykoterapi og biologiske behandlingsmetoder. Motivene for å skrive denne er folkeopplysning og hjelp til selvhjelp samt i noen grad å vise hvordan den depressive lidelsen og personligheten spiller sammen. Dette er ingen deprimerende bok, for utvalget av intervjuede personer med forskjellige typer depresjon er alle bemerkelsesverdige mennesker med suksesshistorier. Men de er dermed lite representative. 
Dette er resultatet av forfatterens omfattende research i fag-og skjønnlitteratur, tre egne depressive sammenbrudd som beskrives detaljert, og intervjuer med vellykkede pasienter og sentrale psykiatere og kliniske psykologer i USA. Den er nesten for omfattende til å leses fra perm til perm, men de enkelte kapitlene kan leses uavhengig av hverandre. Fire kapitler omhandler depresjon, sammenbrudd, rusmiddelavhengighet og selvmord - der hans egen historie står sentralt for å belyse depresjonen i et fenomenologisk perspektiv. I ett kapittel gjennomgår han ulike psykiatriske behandlingsmetoder, i et annet alle mulige alternative hjelpemåter som finnes. Depresjonsbegrepets historie, sammenhenger mellom depresjon og fattigdom, helsepolitikken i USA og depresjon samt evolusjonsperspektivet på depresjon gjennomgås også i ganske stor detalj. Siste kapittel heter Håp, og her er budskapet at man ikke må la depresjonen stjele uker, måneder og år av ens liv, men søke tidlig hjelp og arbeide med den selv også.

Er det en bok å anbefale pasienter? Jeg vil nøle med det. Dels er den for omfattende, tar med likt og ulikt, skiller ikke mellom hva som er personlighetsproblematikk og hva som har med depresjonslidelsen å gjøre og forklarer dermed «alt» ut fra at personen er depressiv. Dels er også behandlinger som refereres preget av amerikansk multifarmakologi med opptil 11 medikamenter til én pasient, og av en typisk amerikansk splitt mellom «psykiateren min», «psykofarmakologen min» og "psykoterapeuten min». For en deprimert pasient eller en pårørende kan kapitlene om behandling og alternativ behandling virke kaotiske når alt fremstilles som like bra eller like dårlig, uten angivelse av indikasjoner og kontraindikasjoner.

Er det en bok for leger? Kanskje for noen som vil ha en omfattende, men populærvitenskapelig oversikt over hvordan det oppleves å være deprimert og hvordan depresjon preger liv og samfunn.

Publisert: 17. juni 2014. Tidsskr Nor Legeforen. DOI:10.4045/tidsskr.14.0320

(C) Tidsskrift for Den norske legeforening 2023. Lastet ned fra tidsskriftet.no 26. april 2023. 